\title{
PDHX wt Allele
}

National Cancer Institute

\section{Source}

National Cancer Institute. PDHX wt Allele. NCI Thesaurus. Code C155318.

Human PDHX wild-type allele is located in the vicinity of $11 \mathrm{p} 13$ and is approximately 105 $\mathrm{kb}$ in length. This allele, which encodes pyruvate dehydrogenase protein X component, mitochondrial protein, is involved in the regulation of pyruvate dehydrogenase activity. Mutation of the gene is associated with lactic acidosis due to pyruvate dehydrogenase E3-binding protein deficiency. 